ical characters. They bound to ligand peptide more strongly than wild-type, whereas they were less stable than wild-type. These results indicate that the library with primitive alphabets is available for creating functional proteins as well as the library with a full set of alphabets.

\section{P104 ヘムオキシゲナーゼによるベルドヘム開環機棈}

Ring Opening Mechanism of Verdoheme Catalyzed by Heme Oxygenase

Toshitaka Matsui ${ }^{1}$, Masaki Unno ${ }^{2}$, Masao Ikeda-Saito ${ }^{1},\left({ }^{1}\right.$ Institute of Multidisciplinary Research for Advanced Materials, Tohoku University: ${ }^{2}$ Frontier Research Center for Applied Atomic Sciences, Ibaraki University)

Heme oxygenase (HO) catalyzes degradation of heme to biliverdin, $\mathrm{CO}$ and a free iron to have a variety of physiological functions including heme catabolism and signal transduction. The HO reaction proceeds through three successive oxygenations in which the substrate heme and its degradation intermediates activate $\mathrm{O} 2$ for their self-oxidation. The third oxygenation of the HO catalysis, ring opening of verdoheme to yield biliverdin, is considered as a major rate-determining step; however, this last oxygenation has been least understood in spite of its importance in regulating the $\mathrm{HO}$ activity. We have recently proposed a ring-opening mechanism involving $\mathrm{Fe}-\mathrm{OOH}$ verdoheme and ferryl biliverdin intermediates on the basis of reaction analysis with various hydroperoxides. Crystal structural analysis of verdoheme-HO complexes in this study clearly reveals that the verdoheme-bound ligands can form hydrogen bond with a nearby water molecule. QM/MM calculations based on the crystal structures assure the feasibility of the proposed mechanism and highlight significance of the nearby water molecule in transfering the terminal $\mathrm{OH}$ group of $\mathrm{Fe}-\mathrm{OOH}$ into an $\alpha$-pyrrole carbon to cleave the porphyrin macrocycle. Generation of a low-spin feryl species as a ring opening intermediate was revealed by Mossbauer analysis to support our mechanistic proposal.

3P105

\section{ウシ心筋チトクロム酸化酵素 $\quad F$ 型中間体の X 線結晶構造解 析}

$\mathrm{X}$-ray structural analysis of catclytic $\mathrm{F}$ intermediates in bovine cytochrome c oxidase

Ai Sasaki ${ }^{1}$, Kazumasa Muramoto ${ }^{1,2}$, maeda tomoko ${ }^{1}$, Kyoko Shinzawa-Itoh ${ }^{1}$, Eiki Yamashita ${ }^{3}$, Tomitake Tsukihara ${ }^{2,3}$, Shinya Yoshikawa ${ }^{1,2}$, ( ${ }^{1}$ Department of Life Science,Univercity of Hyogo: ${ }^{2}$ Picobiology Institute, Department of Life Science, Univercity of Hyogo: ${ }^{3}$ Institute for Protein Research Osaka Univercity)

Cytochrome $c$ oxidase $(\mathrm{CcO})$ catalyzes oxygen reduction coupled to the proton pump across the membrane. The oxygen reduction site consists of heme and copper atom. In the oxygen reduction cycle, several intermediate forms have been identified by visible absorption and resonance Raman spectroscopy. The oxygen-oxygen bond of oxygen molecule is broken on the formation of the $\mathrm{P}$ intermediate. In the next step, delivery of an electron and a proton to the catalytic site generates the F-form. X-ray structures of the F-form have not been determined yet. In this study, we prepared the crystals of bovine $\mathrm{CcO}$ containing F-form and performed X-ray structural analysis.It is known that reaction of the resting oxidized $\mathrm{CcO}$ with excess amount of hydrogen peroxide forms the $\mathrm{F}$ intermediate. The bovine $\mathrm{CcO}$ crystal in the resting oxidized state was treated by hydrogen peroxide, which caused the absorption change at $580 \mathrm{~nm}$ indicating the $\mathrm{F}$ intermediate formation. The resultant absorption spectrum indicated that although both the F-form and P-form exist in the crystal, the F-form is a dominant species. X-ray structural analysis showed that the electron density is located near $\mathrm{Fe}_{a 3}$ and $\mathrm{Cu}_{B}$. The result indicates that, one oxygen atom binds to $\mathrm{Fe}_{a 3}$ and another oxygen atom binds to $\mathrm{Cu}_{B}$ in the F-form. Structure of the proton transfer pathway in the F-form is currently analyzed.

\section{P106 \\ シアン化物結合混合原子価型ウシ心筋チトクロム酸化酵素の結} 晶の調製

A preparation of the crystalline cytochrome $c$ oxidase in the cyanide bound mixed valence state from bovine heart.

Masao MOCHIZUKI, Kazumasa MURAMOTO, Kyoko SHINZAWA-ITOH, Shinya YOSHIKAWA, (Graduate School of Life Science, University of Hyogo)

Cytochrome $c$ oxidase contains four redox-active metal centers, $\mathrm{Fe}_{a}, \mathrm{Fe}_{a 3}$, $\mathrm{Cu}_{A}, \mathrm{Cu}_{B}$. For elucidation of the coupling mechanism of the electron transfer and the $\mathrm{H}^{+}$pumping, analyses of the interactions between these metal centers is indispensable. Various respiratory inhibitors have been used for probing these interactions. Cyanide would be an excellent probe for examination of the effects of oxidation state of $\mathrm{Cu}_{B}$ on the ferric $\mathrm{Fe}_{a 3}$, since cyanide is the only reagent stabilizing $\mathrm{Fe}_{a 3}$ in the ferric state.

It is well known that $\mathrm{Fe}_{a 3}{ }^{3+}$-cyanide derivative is stable for 24 hours or longer in the presence of excess amount of dithionite. However, in the bovine heart enzyme in the crystals, cyanide did not stabilize $\mathrm{Fe}_{a 3}{ }^{3+}$-cyanide completely as in the case in solution. Therefore, the stability of the $\mathrm{Fe}_{a 3}{ }^{3+}$-cyanide derivative of the enzyme in solution was reexamined for the present enzyme preparation. Upon addition of excess amount of dithionite, $\mathrm{Fe}_{a}{ }^{3+}$ was reduced within a few second while $\mathrm{Fe}_{a 3}{ }^{3+}$-cyanide derivative was reduced much slower. It took about 12 hours for the complete reduction. No structural basis for the difference in the stability is known. However, the integrity of the present preparation, providing single crystals diffracting high resolution $\mathrm{X}$-rays, is obvious. The rate of $\mathrm{Fe}_{a 3}{ }^{3+}$ reduction much slower than that of $\mathrm{Fe}_{a}{ }^{3+}$ strongly suggests that a mixed valence cyanide derivative in which only $\mathrm{Fe}_{a 3}$ is in the oxidized state can be prepared. We are now searching the conditions for giving the derivative in the single crystals.

\section{P107 \\ ヒトヘモグロビンの四次構造転移における芳香族アミノ酸残基} の関与 : 近紫外円二色性による研究

Involvement of aromatic residues in the quaternary structure transition of human hemoglobin: A near-UV circular dichroism study

Masako Nagai, Kiyohiro Imai, Yukifumi Nagai, (Research Center for Micro-Nano Technology, Hosei University)

The negative circular dichroism(CD) band at $287 \mathrm{~nm}$ of $\mathrm{Hb} \mathrm{A}$ known as a T-state marker has been supposed to derive from the changes of Tyr and Trp residues at the $\alpha 1-\beta 2$ subunit interface upon oxygen dissociation. To identify the aromatic residue responsible for the $\mathrm{CD}$ band, we have synthesized five recombinant $\mathrm{Hbs}$ in $E$. coli in which non aromatic residue is substituted for Tyr or Trp residue; $\mathrm{rHb}(\alpha 14 \operatorname{Trp} \rightarrow \mathrm{Leu}), \mathrm{rHb}(\beta 15 \operatorname{Trp} \rightarrow \mathrm{Leu}), \mathrm{rHb}(\beta 37 \operatorname{Tr} \mathrm{r} \rightarrow$ His $)$, $\mathrm{rHb}(\alpha 42 \mathrm{Tyr} \rightarrow \mathrm{Ser})$, and $\mathrm{rHb}(\beta 145 \mathrm{Tyr} \rightarrow \mathrm{Thr})$. We examined the near-UV CD spectra of these $\mathrm{rHbs}$ and $\mathrm{Hb}$ Rouen $(\alpha 140 \mathrm{Tyr} \rightarrow \mathrm{His})$ in the oxy-form. The $\mathrm{CD}$ spectra of individual aromatic residue were extracted from the difference spectrum between $\mathrm{Hb} \mathrm{A}$ and each mutant. Negative $\mathrm{CD}$ band appeared at $285 \mathrm{~nm}$ for $\alpha 14 \operatorname{Trp}$ and $\beta 15 \operatorname{Tr}$, while positive CD bands at 280 and $287 \mathrm{~nm}$ for $\beta 37$ Trp. The $\alpha 140$ Tyr exhibited a positive CD band at $284 \mathrm{~nm}$, while $\alpha 42 \mathrm{Tyr}$ and $\beta 145$ Tyr showed a negative band at 274 and $286 \mathrm{~nm}$, respectively. The CD bands for $\beta 37$ Trp, $\beta 145 \mathrm{Tyr}$, and $\alpha 140$ Tyr residues distinctly changed toward negative upon deoxygenation. On the other hand, the negative CD band of $\alpha 42$ Tyr changed became positive. While the CD bands for $\alpha 14 \operatorname{Trp}$ and $\beta 15 \operatorname{Trp}$ remained unchanged. We concluded that changes in $C D$ bands arising from $\beta 37 \mathrm{Trp}, \alpha 140 \mathrm{Tyr}, \beta 145 \mathrm{Tyr}$ and $\alpha 42 \mathrm{Tyr}$ residues contributed to the appearance of the near-UV CD bands in different manners. To assign individual signals of $\mathrm{CD}$ band to each aromatic residue, we examined the effect of environments on CD spectra using model compounds of Tyr and Trp.

3P108 Spectoroscopic analyses of heme-acceptor region of Bach2 protein

Murayama Kazutaka ${ }^{1}$, Watamabe-Matsui Miki ${ }^{2}$, Matsui Toshitaka ${ }^{3}$, Ikeda-Saito Masao ${ }^{3}$, Igarashi Kazuhiko ${ }^{2}$, ( ${ }^{1}$ Tohoku University, School of Biomedical Engineering: ${ }^{2}$ Tohoku University, School of Medicine: ${ }^{3}$ Tohoku University, Institute of Multidisciplinary Research for Advanced Materials)

The B cell-specific transcriptional repressor Bach2 possesses the basic regionleucine zipper (bZip) motif that mediates dimer formation with Maf oncoproteins and DNA binding. It has been found that heme inhibits the DNA binding activity of Bach2 in vitro and induces polyubiquitination and degradation of Bach2 in B cells. Furthermore, we found that heme bound directly to Bach2 in vitro through multiple Cys-Pro (CP) motifs by spectroscopic analyses. However, the regulation mechanism by heme is still unknown. Here, we are approaching to reveal this question with several spectoroscopic measurements. Bach2(331-489) remained after limited proteolysis, suggesting that this region may be a domain-like form. While this region contains three of five CP motifs, secondary structure predictions by PSIPRED assigned no structural element for Bach2(331-489). Circular dichroism (CD) measurements in far-UV region indicated that Bach2(331-520) is almost random coil. Measurements in near-UV region indicated remarkable changes of spectrum in the presence of heme between Bach2(331-520) wild type and CP-mutant (cystein to alanine at the CP motifs). This result suggested that the CP motifs are very important to accept heme. UV-Vis spectoroscopic measurements also supported heme binding in this region. It is considered that Bach2(331-489) is not just randomly fluctuating but have a domain-like form and functions as a heme acceptor using the three CP motifs.

\section{P109 酸素化へモグロビン、ミオグロビンの酸化反応：p H 依存性 と温度依存性}

Oxidation reaction of oxyhemoglobin and oxymyoglobin: pH- and temperature-dependences

Wakasa Yuya ${ }^{1}$, Iizuka Tetsutaro ${ }^{2}$, Imai Kiyohiro ${ }^{2},\left({ }^{1}\right.$ Dept. of Frontier Biosci., Graduate Sch. of Engi., Hosei Univ.: ${ }^{2}$ Dept. of Frontier Biosci., Fac. of Biosci. and Appl. Chem., Hosei Univ.) 